\title{
Implementation Cloud Enabled SaaS Services in Library Automation: A Study of Government Initiatives in India
}

\author{
Subhajit Panda ${ }^{1}$ and Dr.Rupak Chakravarty ${ }^{2}$ \\ 'Assistant Librarian, Chandigarh University, Mohali, Punjab (India) \\ Email: subhajit.e9641@cumail.in \\ Phone: 8250789798 \\ ${ }^{2}$ Professor, Department of Library and Information Science Panjab \\ University Chandigarh (India) \\ Email: rupak@pu.ac.in \\ Phone: 7696602011
}

\begin{abstract}
Cloud computing is one of the exciting developments among the technocrats and animated librarians over the world as a technology solution as well as resource sharing venture. The study discusses the root causes of the issues associated with the conventional library management framework and provides the advantages, issues \& challenges of using cloud-enabled technology when introducing library automation. Cloud services eliminate duplication data creation \& efforts, library resources utilize more because of better accessibility \& visibility, scalable enough for integration with existing systems, less maintenance (cloud-enabled SAAS model), provision of on-cloud security \& authentication and central database \& backup-restore system offered disaster recovery challenge. As the present study concentrates on government initiatives, the NIC National CloudGI Cloud, Meghraj and famous cloud-enabled Government supported proprietary software (ILMS), run using a multi-tenet SaaS model of Meghraj is the selected area for the research. The stats show that, among the 46 library clusters, JNV Libraries Network Cluster No. 1 \& JNV Libraries Network Cluster No. 2 are top two clusters with contains $300 \& 287$ libraries, respectively. e-Granthalaya gives the provision of Web-Based OPAC, Mobile Based OPAC \& Android Mobile App for implementation \& use of e-Granthalaya in any library.
\end{abstract}


To date, 5364 official implementations have been completed, including 5163 in various states in India including Maharastra as a top State 1797 implementations) and New Delhi as a top District 456 implementations).

Keywords: Cloud Computing, Library Automation, SAAS, PAAS, LAAS, STASS, Meghraj, GI Cloud, National NIC Cloud, eGranthalaya, ILMS

\section{Introduction:}

E-readiness, i.e., the combination of infrastructural preparedness, data preparedness, human preparedness \& technological preparedness; is essential for developing e-governance in a country. In India. eGovernance has gradually developed from the computerization of government departments to ICT initiatives such as citizen centricity, service orientation and transparency that encapsulate the finer points of governance; and implement it across the various arms of Government at National, State, and Local levels. For this purpose, various State Governments \& Central Ministries take a large number of ICT initiatives under the National e-Governance Plan (NeGP) to improve the delivery of public services and simplify the process of accessing them. The NeGP is a government approved, country-wide plan to integrate those initiatives into a collective vision \& a shared cause. It comprising of 27 Mission Mode Projects and 8 components (18 May 2006) and later 4 more projects (i.e., Health, Education, PDS and Posts) were introduced (in 2011). The vision statement of NeGP can be articulated as, "Make all Government services accessible to the common man in his locality, through common service delivery outlets, and ensure efficiency, transparency, and reliability of such services at affordable costs to realise the basic needs of the common man". [1]

The implementation of e-Governance system of a country depends upon the present economics, academic structure, research facilities, health issues and involvement of government ministry. Again, the academic structure \& research facilities depends on the current education system and Lectures, Laboratory \& Library (LLL) is its development arm [2]. The Libraries and librarians are the essential providers of information as they organise \& disseminate accurate \& reliable information for academic as well as social community. The automation of the library is important to eliminate the workload of repetitive works in the areas of acquisitions, circulation and technical section of the library and free up the library staff so that they can 
better serve their patrons. Automation efforts in libraries have moved from standalone database systems to cloud-based systems, traversing generations of library management system (LMS) and integrated library management system (ILS) in between [3]. At present, there are only two famous cloud-enabled proprietary software are available in India, e-Granthalaya and CybrarianTM and among them first one has government support and run using multi-tenet SaaS model of NIC National Cloud/Gl Cloud, Meghraj.

\section{Background Study:}

Research on-cloud computing has been conducted in various domains, and library automation also not a new field of research. Some such important studies are discussed here to provide a preliminary idea of the present study, its need \& importance, and how it adds to the existing literature.

Srivastava (2018) explained the importance of cloud computing in e-governance and briefly described the various projects available online, which are using the cloud services [4]. In his paper, Sandeep (2015) discussed the digital library management software DSpace \& E-Granthalaya that are used to assimilate and disseminate information to the world audience [5]. Mohammed and Ibrahim (2014) analysed the benefits and challenges of cloud computing over e-government systems, reviewed the existing literature on the proposed models and further classified and critically analysed the different types of reviewed models [6]. Akula, Narasimha and Saikumar (2013) examined how this newly emerged paradigm of Cloud Computing Services can be helpful for e-Governance in India [7]. Chandra and Bhadoria (2012), in their study focused on the role of cloud computing in the effective implementation of NeGP of Government of India [8]. In their paper, Barman and Das (2011) presented and analysed the importance of automation along with software in a special library, described the various features of the ILMS e-Granthalaya, its suitability \& limitations for the special libraries [9]. Matoria, Upadhyay and Moni (2007) described the development of the library management system, e-Granthalaya, for public libraries in India and outlined the challenges and potential of a full-scale deployment of this software at a national level [10]. One such study by Majumdar (2005) for government Libraries indicated that $50 \%$ libraries in this sector do not have computers and those have these are not used such facility for library automation [11]. 


\section{Scope of the Study:}

The present study explores the difficulties that library professionals face in disseminating information through the conventional library management system and the use of cloud services as a solution for the same. In particular, this study identifies $\&$ discuss the Government Initiative Cloud (GI Cloud) or National NIC Cloud, Meghraj and its SaaS initiative e-Granthalaya, a cloud-enabled proprietary software (or integrated library management software) for enabling library automation in India.

\section{Objectives:}

I. To identify problems arise in traditional library management system

II. To illustrate the need and importance of cloud computing in automating library

III. To discuss about the Government initiate GI Cloud, Meghraj; its adoption \& implementation

IV. To study about the Government supported cloud-enabled proprietary software, e-Granthalaya

\section{The Problem Statement:}

The use of small-scale computer system in library starting was starting form 1960-65 onwards (e.g. first computer system delivered in the Data Processing Office of Library of Congress in 1964) [12]. These are isolated, small-scale \& scattered in the pattern due to nonavailability of any globally recognised standard. Though as a primary approach, it gets succeed to a certain level; due to lack of an integrated approach, it faces the following challenges [13]:

a) Duplication of Data and Efforts: In the traditional method of library management, the information available in one section of the library is inaccessible from the other section due to the lack of standardisation and uniformity in platform data \& software. Moreover, instead of the mutual sharing of data \& other information, each section creates its own format according to the requirement; which led to duplication of data, time, effort \& human resources.

b) Job Stress: Due to lack of integration, duplication of data \& efforts and repetitive works mainly in circulation \& technical section generate work-stress among library staff. Moreover, by performing such repetitive \& stressful works, they are demotivated for doing something new for the benefits of the users of the library. It decreases their work efficiency \& work speed too. 
c) Resource Utilisation: The demand of library users changes time to time. Now an active library user demand information more than the document. Sometimes the infrastructure \& resource availability of traditional system can't cope with the maximum demand, and on other side, some resources are underutilised due to the lack of user awareness about library resources.

d) Less Scalability: The scalability of traditional library system can't define exactly. It also suffers software upgradation, hardware infrastructure \& customer support to meet long time objectives and additional new requirements.

e) Less Visualisation: Due to the lack of integration \& marketing strategy of the traditional library system, the resources of the library and the library services are not properly visible to its user. As a result, there is a lack of utilisation of library resources and a user can't get proper benefit from the available library services.

f) High Maintenance: Traditional library system requires regular maintenance, human resources and time to work smoothly. In addition, the adjacent and lifelong maintenance cost is also high.

g) Lack of Security: It is difficult to ensure adequate security in a traditional library system because of the data centres and equipment are distributed section wise.

h) Disaster Recovery: Traditional library system can't capable of recovering data \& other library information at the time of any disaster. Due to the unorganised \& scattered structure, there was no central database and no alternate site to save data as a backup.

6. Government of India's GI Cloud (or NIC National Cloud), Meghraj:

Cloud computing has the potential to transform the way IT is consumed and managed, resulting in improved cost efficiencies, accelerated innovation, faster time-to-market, and the ability to scale applications on demand. The Department of Electronics and IT (DeitY) of Government of India has embarked upon an ambitious project termed as 'GI Cloud' (also known as NIC National Cloud), to take advantage of the benefits of the cloud-based services. The government departments \& agencies used this GI Cloud to enable the cloud computing environment, which will allow the government to utilise cloud computing for efficient e-service delivery. [14]

\subsection{Architectural vision of GI Cloud:}

Gl Cloud's architectural vision focuses on a series of distinct cloud computing environments distributed across multiple locations. 
based on existing (SWANs, NKN, NOFN integration) or new (augmented) infrastructure, adopting a set of common Indian government protocols, guidelines and standards. A single GI Cloud Services Directory will publish the GI Cloud services, while multiple National and State Clouds are predicted to consist of the GI Cloud. Managed Service Providers (MSPs) can engage the agencies responsible for running and managing the National and State Clouds to manage the respective cloud computing environments (see Figure 1).

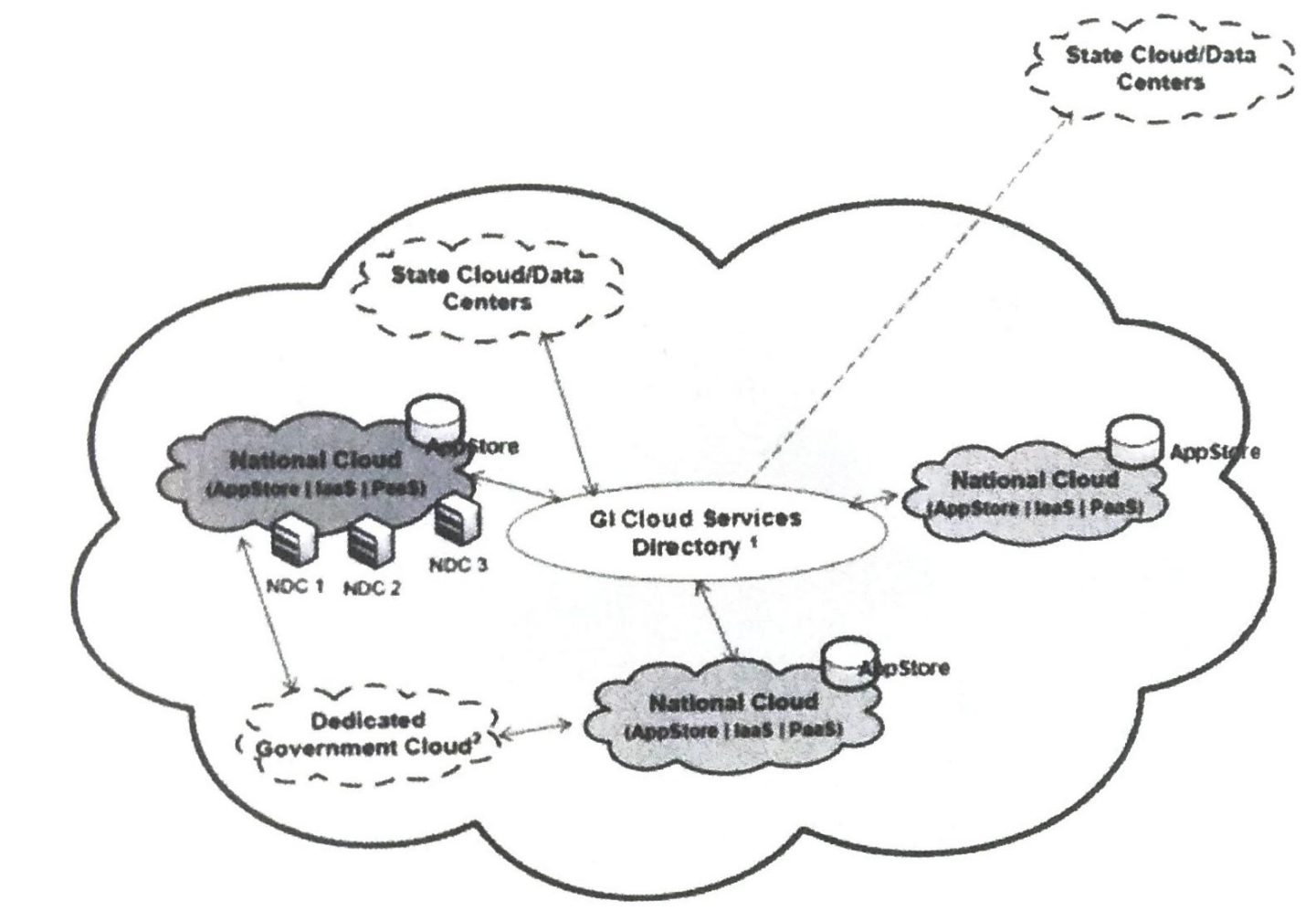

' Single Portal tor Service Delivery

'Built by private cloud providers

Figure 1: Architectural Vision of GI Cloud Environment

As a modern model of offering services and enhancing the efficacy of its ICT activities, most governments are looking to explore cloud computing. Cloud adoption by the government happens at a slower pace than in the private sector. It is expected to intensify, however international governments are exploring for non-critical applications the option of a public cloud, as follows (see Table 1):

\begin{tabular}{|l|l|l|}
\hline $\begin{array}{c}\text { International Governments' } \\
\text { Initiative }\end{array}$ & Private Cloud & Public Cloud \\
\hline $\begin{array}{l}\text { Federal Government Cloud } \\
\text { Initiative }\end{array}$ & Yes & Yes \\
\hline UK Government Cloud & G-Cloud & Yes \\
\hline
\end{tabular}




\begin{tabular}{|l|l|l|}
\hline Initiative & \multicolumn{2}{|c|}{} \\
\hline EU Cloud Initiative & Yet to come with a strategy \\
\hline Australia Cloud Initiative & Yes & Yes \\
\hline Singapore Cloud Initiative & $\begin{array}{l}\text { Central G- } \\
\text { Cloud \& agency } \\
\text { cloud }\end{array}$ & Yes \\
\hline
\end{tabular}

Table 1: International Governments 'Cloud Initiatives in Private \& Public sector)

\section{Service Models of GI Cloud:}

The following four types of service models offered by The GI Cloud, Meghraj (see Table 2) [14, 15, 16];

\begin{tabular}{|c|l|l|}
\hline SN & $\begin{array}{l}\text { Service } \\
\text { Models }\end{array}$ & \multicolumn{1}{|c|}{ Description } \\
\hline 1 & IaaS & $\begin{array}{l}\text { Infrastructure as a Service: in this case, costly } \\
\text { infrastructure is provided by the IaaS provider \& } \\
\text { the library need not to buy them. GI Cloud IAAS } \\
\text { services provide infrastructure resources e.g. } \\
\text { CPU, disk storage, hardware installation } \\
\text { equipment, memory etc. Libraries then capable of } \\
\text { use their licences for operating system \& } \\
\text { application software. }\end{array}$ \\
\hline 2 & PaaS & $\begin{array}{l}\text { Platform as a Service: in this case, a service } \\
\text { provider offers access to a cloud-based } \\
\text { environment in which libraries can build \& } \\
\text { deliver applications \& services. The provider } \\
\text { supplies underlying infrastructure. }\end{array}$ \\
\hline SaaS & $\begin{array}{l}\text { Software as a Service: in this case, a service } \\
\text { provider offers access to vendor's cloud-based } \\
\text { Software \& the libraries need not to install } \\
\text { applications on their local devices. Instead, the } \\
\text { applications reside on a remote cloud network } \\
\text { accessed through the web or an API and with } \\
\text { which libraries can store and analyse data and } \\
\text { collaborate on projects. }\end{array}$ \\
\hline
\end{tabular}




\begin{tabular}{|l|l|l|}
\hline 4 & StaaS & $\begin{array}{l}\text { Storage as a Service: in this case, a service } \\
\text { provider centrally integrated storage solution. It is } \\
\text { better than the traditional system of storage and } \\
\text { the complexities involved in storing data at } \\
\text { multiple places is much reduced in this system. }\end{array}$ \\
\hline
\end{tabular}

Table 2: Service Model of GI Cloud/NIC National Cloud

In addition, GI Cloud (Meghraj) also provides a certain service support like server backup, server antivirus, network firewall, server vulnerability assessment, etc $[4,14]$.

\section{Implementation of GI Cloud: As a Solution of the Problem Statement:}

Does the GI Cloud capable of providing a satisfactory solution to the problem statement describe above? To find its answer, it is needed to examine the practical implementation of GI Cloud infrastructure in the library management system. After thorough understanding the feature of GI Cloud, it can be considered that the cloud computing infrastructure of GI Cloud functioned as key drivers \& it also has some potential benefits. On the other side, though cloud computing is not a new technology, its use in the library is yet to mature both in terms of technology and e-readiness as well as adoption by the user community. So, it is clear to understand that adoption of cloud computing by the library provides several benefits and associated with certain risks \& challenges that are tabulated (see Table 3) below:

\begin{tabular}{|c|l|c|l|}
\hline SN & \multicolumn{1}{|c|}{ Benefits } & SN & \multicolumn{1}{|c|}{ Risks and Issues } \\
\hline 1 & $\begin{array}{l}\text { Optimum utilisation of } \\
\text { existing infrastructure: GI } \\
\text { Cloud can easily integrate } \\
\text { with existing infrastructure } \\
\text { used in the library, and } \\
\text { additionally with enabling its } \\
\text { cloud feature it reduces } \\
\text { duplication of cost and effort. }\end{array}$ & $\mathbf{1}$ & $\begin{array}{l}\text { Design } \\
\text { Appearance: There } \\
\text { is a vital difference in } \\
\text { design \& appearance } \\
\text { between traditional } \\
\text { system \& GI Cloud in } \\
\text { order to integrate lost } \\
\text { of customisation } \\
\text { required on the } \\
\text { traditional system. }\end{array}$ \\
\hline 2 & $\begin{array}{l}\text { Rapid deployment and } \\
\text { reusability: with its Cloud } \\
\text { Computing functions, GI } \\
\text { Cloud can enable rapid }\end{array}$ & $\mathbf{2}$ & $\begin{array}{l}\text { Integration with } \\
\text { legacy environment: } \\
\text { In order to have a } \\
\text { fully operational }\end{array}$ \\
\hline
\end{tabular}




\begin{tabular}{|c|c|c|c|}
\hline & $\begin{array}{l}\text { deployment of more than one } \\
\text { library services } \\
\text { simultaneously \& integration } \\
\text { between sections ensure } \\
\text { reusability of data with less } \\
\text { effort. }\end{array}$ & & $\begin{array}{l}\text { cloud environment } \\
\text { integration with } \\
\text { existing on premise } \\
\text { legacy applications } \\
\text { are required though in } \\
\text { majority of time it } \\
\text { may be limited, } \\
\text { leading to increased } \\
\text { complexity. }\end{array}$ \\
\hline 3 & $\begin{array}{lr}\text { Manageability } & \text { and } \\
\text { maintainability: GI Cloud } \\
\text { provides a single centrally } \\
\text { organised } \\
\text { providing integrated visibility } \\
\text { and control helping library } \\
\text { sections to dispense with the } \\
\text { requirement of lengthy } \\
\text { procurement } \\
\begin{array}{l}\text { maintenance } \\
\text { infrastructure. }\end{array}\end{array}$ & 3 & $\begin{array}{l}\text { Licencing: } \text { Existing } \\
\text { software-licencing } \\
\text { models may not } \\
\text { facilitate cloud } \\
\text { deployment, } \\
\text { especially from the } \\
\text { point of cloud service } \\
\text { delivery. }\end{array}$ \\
\hline 4 & $\begin{array}{l}\text { Scalability: Applications and } \\
\text { infrastructure deployed on } \\
\text { the common GI Cloud } \\
\text { platform can take advantage } \\
\text { of the virtualized nature of } \\
\text { the cloud to scale as required } \\
\text { and becomes more useful for } \\
\text { applications where there is a } \\
\text { burst of demand for e- } \\
\text { resources at regular intervals. }\end{array}$ & 4 & $\begin{array}{l}\text { Loss of Control: The } \\
\text { loss of control may } \\
\text { lead to resistance to } \\
\text { change. As the need } \\
\text { to maintain servers } \\
\text { and other data centre } \\
\text { infrastructure } \\
\text { diminishes, the form } \\
\text { of the IT function in } \\
\text { government may } \\
\text { change. }\end{array}$ \\
\hline 5 & $\begin{array}{l}\text { Efficient \& affordable } \\
\text { service delivery and agility: } \\
\text { Gl Cloud shall provide the } \\
\text { framework for libraries to } \\
\text { enable the roll out of such } \\
\text { services much faster \& } \\
\text { economically compared to } \\
\text { traditional mode with easy \& } \\
\text { quick access to e-resources \& }\end{array}$ & 5 & $\begin{array}{l}\text { Vendor lock- } \\
\text { in:•Increasing } \\
\text { demand for cloud } \\
\text { computing leads to } \\
\text { creating many } \\
\text { proprietary offers by } \\
\text { individual companies } \\
\text { creating challenges in } \\
\text { migrating data and }\end{array}$ \\
\hline
\end{tabular}




\begin{tabular}{|c|c|c|c|}
\hline & provide user-centric services. & & $\begin{array}{l}\text { applications to the } \\
\text { cloud or switching } \\
\text { cloud providers \& put } \\
\text { customers at } \\
\text { significant risk. }\end{array}$ \\
\hline 6 & $\begin{array}{l}\text { Security: A security } \\
\text { framework for the entire GI } \\
\text { Cloud will lead to less } \\
\text { environmental complexity } \\
\text { and less potential } \\
\text { vulnerability. }\end{array}$ & 6 & $\begin{array}{l}\text { Security and } \\
\text { privacy: In a cloud } \\
\text { environment, there is } \\
\text { some risk pertaining } \\
\text { to confidential } \\
\text { information and } \\
\text { intellectual property, } \\
\text { inappropriate access } \\
\text { to personal and } \\
\text { confidential } \\
\text { information, etc. }\end{array}$ \\
\hline 7 & $\begin{array}{l}\text { Increased user mobility: } \\
\text { Cloud will facilitate user } \\
\text { mobility and collaboration } \\
\text { through shared data and } \\
\text { applications stored in the } \\
\text { cloud when authorised - } \\
\text { anytime, anywhere } \\
\text { availability. }\end{array}$ & 7 & $\begin{array}{l}\text { Location of data: } \\
\text { The dynamic nature } \\
\text { of cloud may result in } \\
\text { uncertainty as to } \\
\text { where data actually } \\
\text { reside (or where it is } \\
\text { in transit) at a given } \\
\text { point in time. This } \\
\text { raises concerns } \\
\text { related to data } \\
\text { ownership, } \\
\text { accessibility, privacy } \\
\text { and security. }\end{array}$ \\
\hline 8 & $\begin{array}{l}\text { Standardisation: GI Cloud } \\
\text { shall prescribe the standards } \\
\text { around interoperability, } \\
\text { integration, library } \\
\text { management, security, data } \\
\text { security and portability, data } \\
\text { types, etc. }\end{array}$ & 8 & $\begin{array}{l}\text { Cloud standards: } \\
\text { Existing cloud } \\
\text { standards pertaining } \\
\text { to implementation, } \\
\text { storage and migration } \\
\text { need to be interpreted } \\
\text { to understand their } \\
\text { applicability for the } \\
\text { Gl Cloud } \\
\text { environment. }\end{array}$ \\
\hline
\end{tabular}

Table 3: Benefits, Risks \& Issues Associated with e-Grantahalya 


\section{E-Granthalaya:}

National Informatics Centre, Ministry of Electronics and Information Technology, Government of India developed e. Granthalaya as a digital platform for the government libraries is provide a complete ICT solution with integrated Library Management Software, Digital Library Module, Cloud hosting environment and a Library Portal (OPAC) with NICSI empanelled Roll-out Services support. This is a government-supported ICT initiative to transform traditional libraries into e-Library, enabling digital library services e.g., in-house library automation, centrally integrated library system. user-centric acquisition, online \& remote access facilities, self-access services, etc. Version 4.0 (latest) of e-Granthalaya offered cloud-ready application \& web-based solutions in an enterprise mode with a centralised database for the cluster of libraries. The cloud services of e-Granthalaya 4.0 availed through NIC National Cloud/GI Cloud (Meghraj) and used PostgreSQL (an Open Source DBMS) as a backend database solution. [17]

Following Table 4 displays the various versions of e-Granthalaya. their hosted platform, year of publishing, DMBS \& target libraries for those specific editions:

\begin{tabular}{|l|c|c|l|l|}
\hline $\begin{array}{l}\text { Technology/Platfor } \\
\text { m used }\end{array}$ & Version & Year & DBMS & Edition \\
\hline $\begin{array}{l}\text { Visual Basic } \\
\text { 6/ASP/HTML }\end{array}$ & 1.0 & 2003 & $\begin{array}{l}\text { MS SQL } \\
\text { Server 7 }\end{array}$ & $\begin{array}{l}\text { Public } \\
\text { Library } \\
\text { Edition }\end{array}$ \\
\hline $\begin{array}{l}\text { Visual Basic } \\
\text { 6/ASP/HTML }\end{array}$ & 2.0 & 2005 & $\begin{array}{l}\text { MS SQL } \\
\text { Server 2000 }\end{array}$ & $\begin{array}{l}\text { Governm } \\
\text { ent } \\
\text { Libraries } \\
\text { Edition }\end{array}$ \\
\hline $\begin{array}{l}\text { VB.NET/ASP.NET } \\
\text { 2.0 }\end{array}$ & 3.0 & 2007 & $\begin{array}{l}\text { MS SQL } \\
\text { Server 2005 }\end{array}$ & $\begin{array}{l}\text { Network } \\
\text { Edition }\end{array}$ \\
\hline $\begin{array}{l}\text { ASP.NET } \\
\text { 4.0/AJAX/JQUERY } \\
\text { /JSON/SilverLight }\end{array}$ & 4.0 & 2015 & $\begin{array}{l}\text { PostGreSQL } \\
\text {-an Open } \\
\text { Source } \\
\text { DBMS }\end{array}$ & $\begin{array}{l}\text { Enterpris } \\
\text { e Edition }\end{array}$ \\
\hline
\end{tabular}

Table 4: Available e-Granthalaya Versions \& Other Specifications 
Similar as a SAAS provider (on-cloud) e-Granthalaya also have some technical specifications \& requirements. As this application is hosted in GI Cloud/NIC National Cloud, Meghraj, libraries need not to install anything and there is nothing to maintain. However, the libraries \& the users must have Desktops with High-Speed Internet Connectivity (with min 4-8 MBPS speed). According to NIC Policy on e-Granthalaya, the software is provided to the government and semi-government organisations only. Among the eligible organisations, which are granted for the implementation of eGranthalaya 4.0 may specify as follows:
a) Government
Libraries
under
Ministries/Departments/Organizations
of
Central/State
Governments
b) Government Public Libraries
c) Kendriya Vidyalayas and Jawahar Navodaya Vidyalayas/MHRD
d) Central/State
Government Schools/Colleges/Polytechnics/Universities
e) Autonomous Bodies/Councils / Research Organizations/National Laboratories/IITs/IIMs/NIITs/PSUs of Centre and States
f) Other Government Academic Institutions funded by Government
g) Indian Embassies
h) Indian Army/Navy /Air Force Libraries

However, the Private \& Aided/Autonomous institutions, universities, colleges, schools are ineligible for the software. To get this software eligible Govt/Semi-govt organisations/libraries may send a scanned copy of duly filled/stamped PI Request Form along with covering letter at rkmatoria@nic.in to initiate the process and the charge for the software is decided Rs.21,275/= from each library opting to use eG4 on NIC Cloud - as a one-time payment for a fiveyear period for hosting, maintenance and Help-Desk support. After registration, the library gets an online account of e-Granthalaya 4.0 with a live link that can be accessed through http://eg4.nic.in by click $\&$ select the particular library cluster \& then Login required for further proceeding.

\subsection{Multi-Lingual Supportability:}

The "eG4" is UNICODE Compliant and supports data entry in the local language. If eG4 runs on a PC with net connectivity, has a built-in tool to use any Indian language by just selecting from 'DropDown' visible on the top part of each web form of eG4. Press "Control 
$\mathrm{g}$ " to activate the selected language. Besides this, Windows 7 and later OS come with pre-loaded "Language Pack" and the user can instat any UNICODE compliant software for typing local languages in their PC. Additionally, 'Google Transliteration IME Tool' available fres and can be installed online from the following URt: http://www.google.com/ime/transliteration/ [18]. Some examples of scripts \& languages supported by eG4 are listed below tsee Table 5 .

\begin{tabular}{|l|l|l|l|}
\hline \multicolumn{1}{|c|}{ Script } & \multicolumn{1}{|c|}{ Font } & \multicolumn{1}{|c|}{ Languages } & \multicolumn{1}{c|}{ Remarks } \\
\hline Devnagari & Mangal & $\begin{array}{l}\text { Sanskrit, Hindi, } \\
\text { Marathi, Kankani, } \\
\text { Nepali }\end{array}$ & $\begin{array}{l}\text { UNICODE/Open } \\
\text { Type Font }\end{array}$ \\
\hline Telegu & Gautami & Telegu & $\begin{array}{l}\text { UNICODE/Open } \\
\text { Type Font }\end{array}$ \\
\hline Gujarati & Shruti & Gujarati & $\begin{array}{l}\text { UNICODE/Open } \\
\text { Type Font }\end{array}$ \\
\hline Gurumukh & Raavi & Pubjabi & $\begin{array}{l}\text { UNICODE/Open } \\
\text { Type Font }\end{array}$ \\
\hline Malayalam & Kartika & Malayalam & $\begin{array}{l}\text { UNICODE/Open } \\
\text { Type Font }\end{array}$ \\
\hline Bengali & Vrinda & $\begin{array}{l}\text { Bengali, Assamese, } \\
\text { Manipuri }\end{array}$ & $\begin{array}{l}\text { UNICODE/Open } \\
\text { Type Font }\end{array}$ \\
\hline
\end{tabular}

\subsection{Cluster Statistics:}

Granthalaya [19]

NIC, MeiTY, Government of India separated \& arranged the libraries in some clusters (see Figure 2) according to their organising body, subject, managing government department, etc. The purpose of having a separate database for a different cluster of libraries is to use the online version of e-Granthalaya for Automation and Networking of libraries. It enables storing and disseminating the catalogue information of documents available in that particular category of libraries as well as other library services hosted in NIC National Cloud and to adopt the concept of shared cataloguing. 


\section{Cluster Statistics}

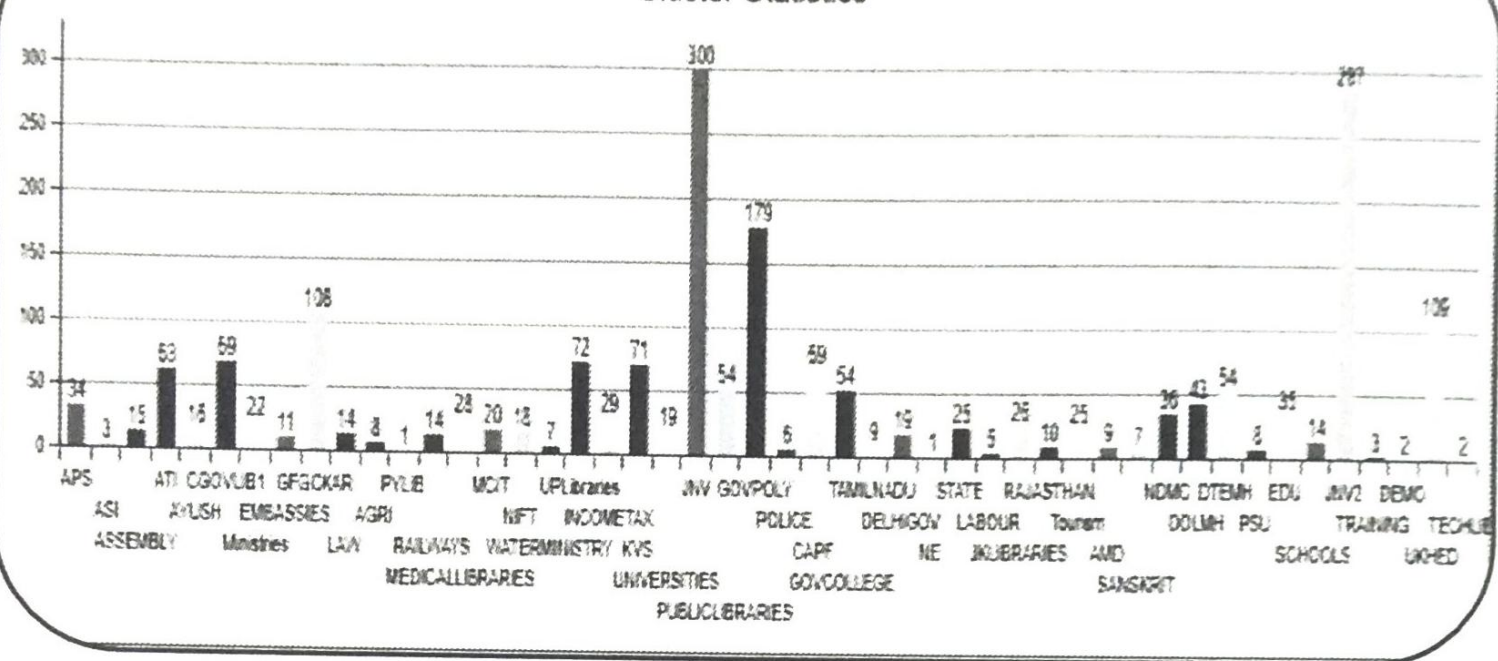

Figure 2: Cluster Statistics [20]

\begin{tabular}{|c|l|c|c|c|c|}
\hline Rank & \multicolumn{1}{|c|}{$\begin{array}{c}\text { Name of } \\
\text { Cluster } \\
\text { Titles }\end{array}$} & $\begin{array}{c}\text { Total } \\
\text { Copies }\end{array}$ & $\begin{array}{c}\text { Total } \\
\text { Members }\end{array}$ & $\begin{array}{c}\text { Libraries } \\
\text { in } \\
\text { Cluster }\end{array}$ \\
\hline 1 & $\begin{array}{l}\text { JNV } \\
\text { Libraries } \\
\text { Network } \\
\text { Cluster No. 1 }\end{array}$ & 1700633 & 1937758 & 106831 & 300 \\
\hline 2 & $\begin{array}{l}\text { JNV } \\
\text { Libraries } \\
\text { Network } \\
\text { Cluster No. 2 }\end{array}$ & 1189465 & 1319377 & 51944 & 287 \\
\hline 3 & $\begin{array}{l}\text { Government } \\
\text { Polytechnics } \\
\text { Libraries } \\
\text { Network }\end{array}$ & 86909 & 368967 & 10847 & 179 \\
\hline 4 & $\begin{array}{l}\text { Uttarakhand } \\
\text { Colleges } \\
\text { Libraries } \\
\text { Network }\end{array}$ & 163833 & 673532 & 2011 & 109 \\
\hline 5 & $\begin{array}{l}\text { Government } \\
\text { First Grade } \\
\text { Colleges, }\end{array}$ & 288821 & 865851 & 46111 & 108 \\
\hline
\end{tabular}




\begin{tabular}{|c|c|c|c|c|}
\hline $\begin{array}{c}\text { Karnataka } \\
\text { Government }\end{array}$ & & & & \\
\hline Total (Top 5) & $\mathbf{3 4 2 9 6 6 1}$ & $\mathbf{5 1 6 5 4 8 5}$ & $\mathbf{2 1 7 7 4 4}$ & 983 \\
\hline All Total (46) & 7723852 & $\begin{array}{c}1197282 \\
8\end{array}$ & 551764 & 2033 \\
\hline
\end{tabular}

Table 6: ('Huster Statistics (Top 5 \& All Total) [20]

Table 6 shows that among the 46 clusters (all total), JNV Libraries Network Cluster No. I \& JNV Libraries Network Cluster No. 2 are top two clusters in terms of number of libraries in that cluster (i.e., $300 \& 287$, respectively). They followed by Government Polytechnics Libraries Network, Uttarakhand Colleges Libraries Network \& Government First Grade Colleges, Karnataka Government contained 179, $109 \& 108$ libraries in their cluster, respectively. It is noted that, the top 5 library cluster obtained more than $48 \%(=983)$ of libraries in total.

\subsection{Available Platform for Implementation e-Granthalaya:}

The National Informatics Centre (NIC) provides three types of digital platforms for the implementation of e-Granthalaya 4.0, viz. eG4 desktop/PC accessible web-based OPAC, Mobile accessible eG4 OPAC and Android based eG4 Mobile App.

a) Web-Based OPAC:

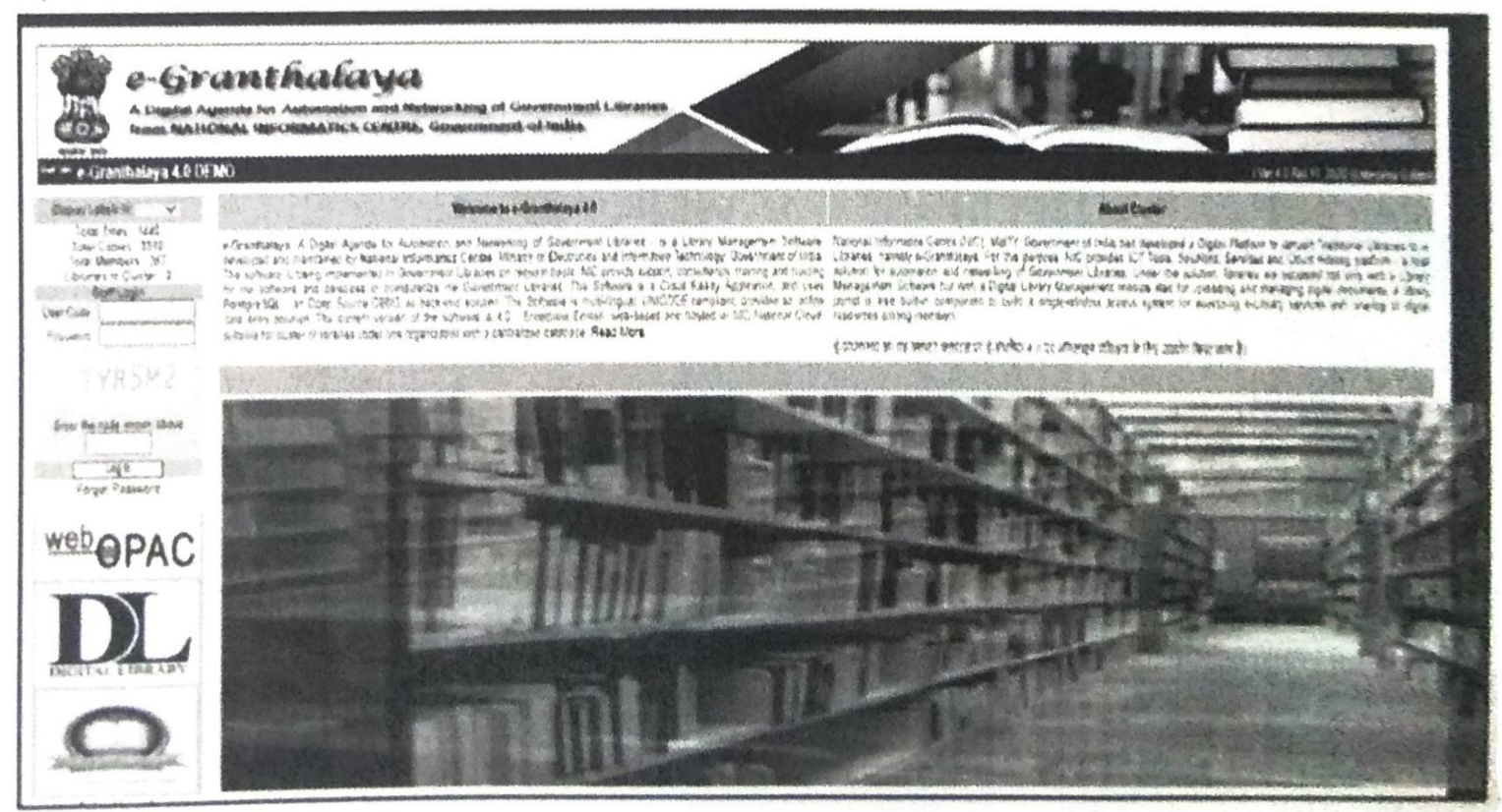

Figure 3: Access eG4 Demo Site

The NIC provides access of e-Granthalaya to the luster of 
libraries of government/semi-govt organisations on request, registration \& payment basis. A library portal is also built-in component to build a single-window access system for accessing eLibrary services with sharing of digital resources among members [21]. There are two Demo Sites (see Figure 3) provided by NIC for practise before making an order. These demo sites are available in https://eg4.nic.in/demo/ and can be logged in through the following user id \& password;

- User 1: DEMOUSER1 and password: Dem\$123 or,

- User 2: DEMOUSER2 and Password: Dem\$123 (Plz use either one)

b) Mobile Based OPAC:

If any user wants to use e-Granthalaya OPAC through a smartphone, s/he can easily do that with the mobile version of eG4, available in https://eg4.nic.in/Mobile/. NIC provides this version of eG4 because all users of the library may not possess a desktop or PC and the web-based OPAC page not smoothly visible in mobile. (see Figure 4)

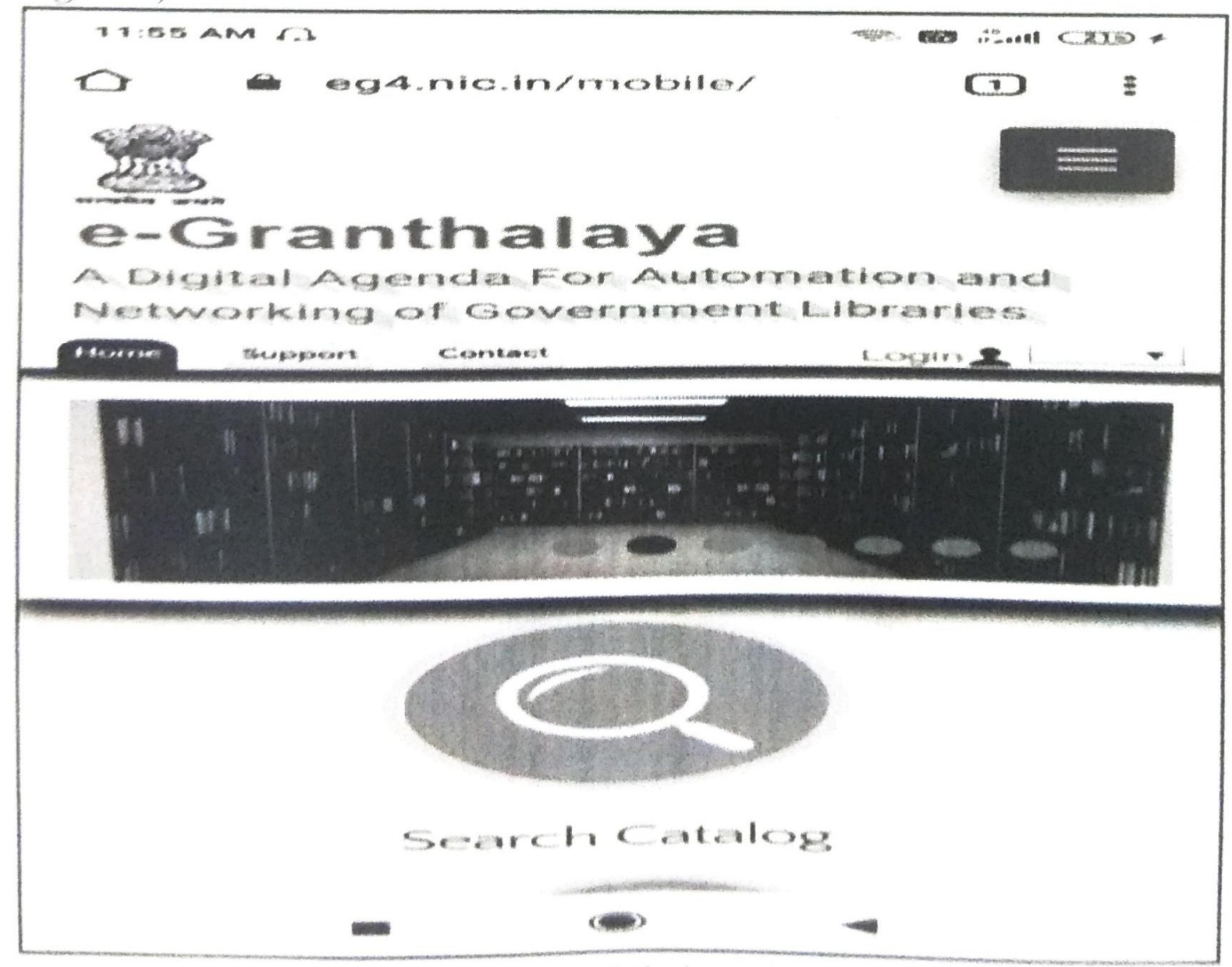

Figure t: ed it Mobile based OPAC 


\section{c) Android based eG4 Mobile App:}

NIC also launched an android based eG4 app for registered library members under any library cluster. The users first have to install the app from Google play store and activate using his mobile number and $\log$ in through proper selection of cluster \& library and after entering the member number. This app provides every functionality available in web OPAC \& mobile OPAC. (see Figure 5 d 6)

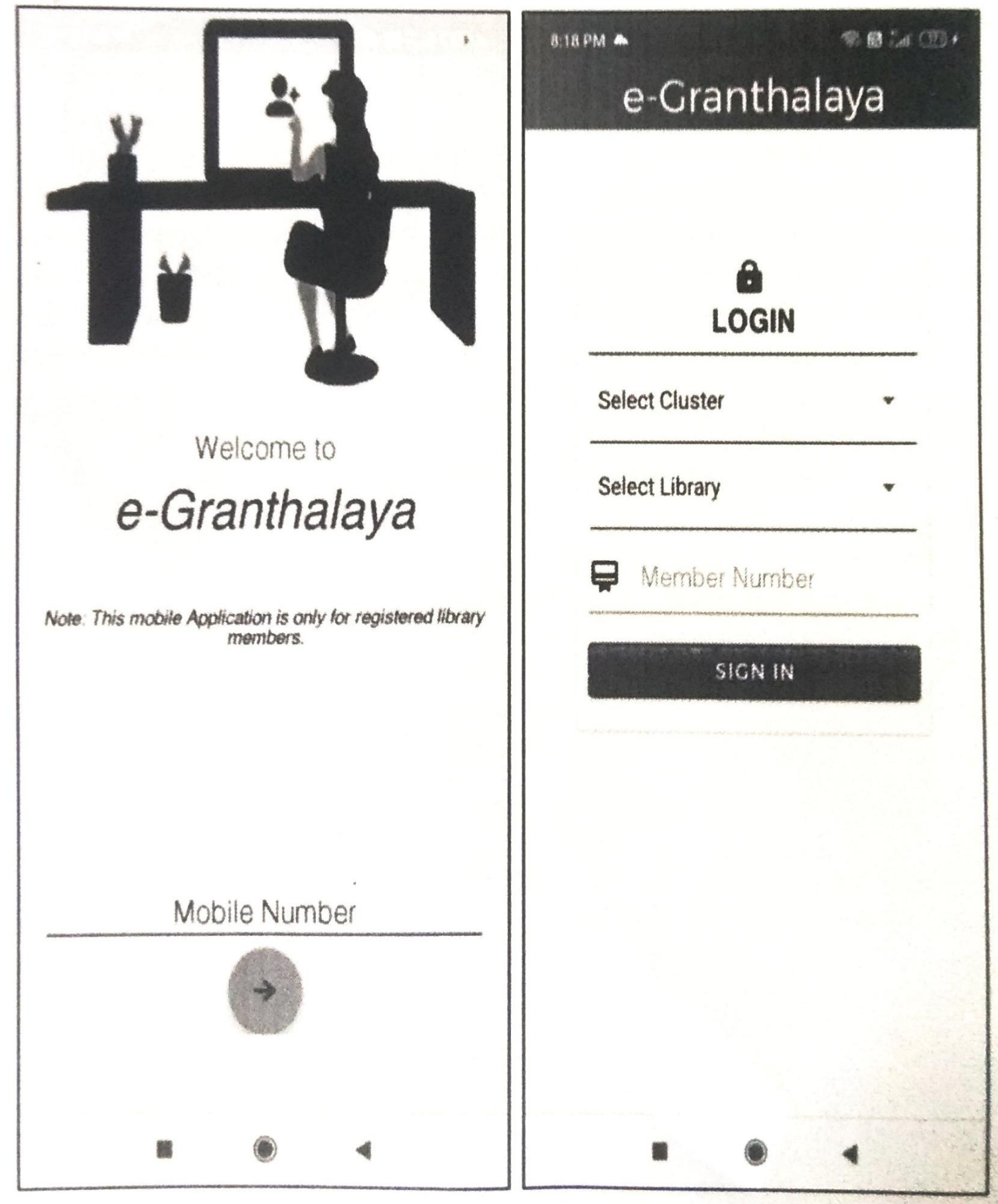

Figure 5 \& 6: Android based eG4 Mobile App 


\section{4. e-Granthalaya Official Implementations:}

As the e-Granthalaya software is provided by NIC to the government and semi-government organisations only, the implementation of e-Granthalaya depends on the availability of government colleges and universities with ICT infrastructure. To date, 5364 official implementations have been completed, including 5163 in various states in India (see Figure 7).

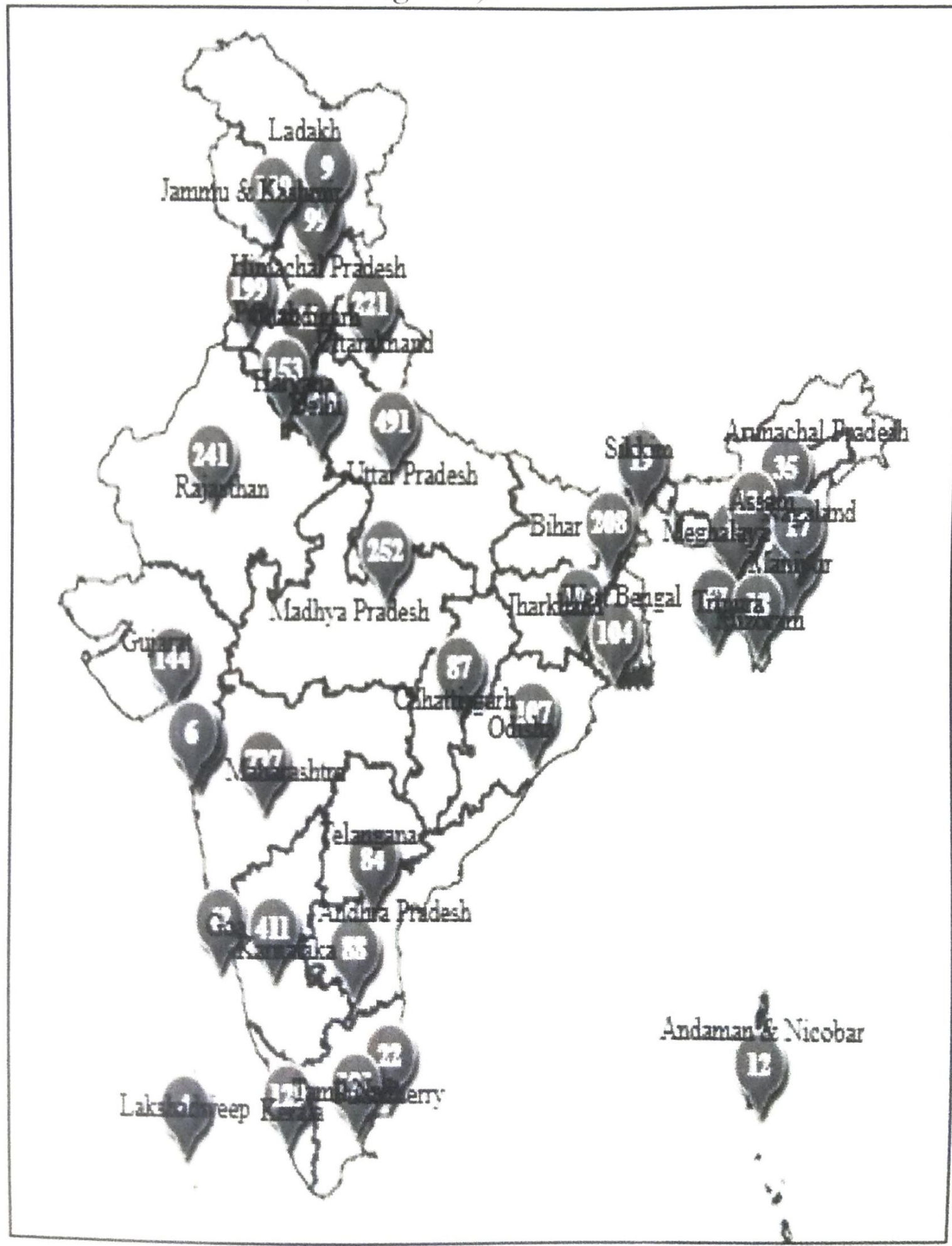

Figure 7: Country-wide Installation Map [22] 
a) State Wise Implementation:

\begin{tabular}{|c|c|c|c|c|c|}
\hline Rank & State Name & $\begin{array}{c}\text { Total } \\
\text { Implementation }\end{array}$ & Rank & State Name & $\begin{array}{c}\text { Total } \\
\text { Implementation }\end{array}$ \\
\hline 1 & Maharashtra & 797 & 20 & $\begin{array}{l}\text { Andhra } \\
\text { Pradesh }\end{array}$ & 88 \\
\hline 2 & Uttar Pradesh & 491 & 21 & Chhattisgarh & 87 \\
\hline 3 & Delhi & 479 & 22 & Telangana & 84 \\
\hline 4 & Karnataka & 411 & 23 & Tripura & 67 \\
\hline 5 & $\begin{array}{l}\text { Madhya } \\
\text { Pradesh }\end{array}$ & 252 & 24 & Chandigarh & 45 \\
\hline 6 & Rajasthan & 241 & 25 & Meghalaya & 45 \\
\hline 7 & Uttarakhand & 221 & 26 & Goa & 42 \\
\hline 8 & Bihar & 208 & 27 & $\begin{array}{l}\text { Arunachal } \\
\text { Pradesh }\end{array}$ & 35 \\
\hline 9 & Punjab & 199 & 28 & Manipur & 24 \\
\hline 10 & Haryana & 153 & 29 & Puducherry & 22 \\
\hline 11 & Gujarat & 144 & 30 & Sikkim & 19 \\
\hline 12 & $\begin{array}{l}\text { Jammu and } \\
\text { Kashmir }\end{array}$ & 139 & 31 & Mizoram & 18 \\
\hline 13 & Assam & 134 & 32 & Nagaland & 17 \\
\hline 14 & Kerala & 129 & 33 & $\begin{array}{l}\text { Andaman and } \\
\text { Nicobar }\end{array}$ & 12 \\
\hline 15 & Tamil Nadu & 121 & 34 & Ladakh & 9 \\
\hline 16 & Odisha & 107 & 35 & $\begin{array}{l}\text { Dadra and } \\
\text { Nagar Haveli }\end{array}$ & 6 \\
\hline 17 & Jharkhand & 104 & 36 & $\begin{array}{l}\text { Daman and } \\
\text { Diu }\end{array}$ & 6 \\
\hline 18 & West Bengal & 104 & 37 & Lakshadweep & 4 \\
\hline 19 & $\begin{array}{l}\text { Himachal } \\
\text { Pradesh }\end{array}$ & 99 & & Total & 5163 \\
\hline
\end{tabular}

Table 7: State Wise Implementation Statistics of e-Gramthalara [22] 
Table 7 indicates that among the 37 states (including union territories) of India, Maharastra, Uttar Pradesh \& Delhi are positioned as the top three states with maximum implementation of e-Granthalaya (797, 491 \& 479, respectively); while Lakshadweep, Daman \& Diu and Dadra \& Nagar Haveli are the least ones (4, 6 \& 6, respectively).

b) District Wise Implementation:

\begin{tabular}{|l|l|l|l|}
\hline Rank & District & Total Implementation & State \\
\hline $\mathbf{1}$ & New Delhi & 456 & Delhi \\
\hline $\mathbf{2}$ & Mumbai & 166 & Maharastra \\
\hline $\mathbf{3}$ & Pune & 101 & Maharastra \\
\hline $\mathbf{4}$ & Bangalore & 92 & Karnataka \\
\hline $\mathbf{5}$ & Patna & 61 & Bihar \\
\hline $\mathbf{6}$ & Chennai & 55 & Tamil Nadu \\
\hline $\mathbf{7}$ & Hyderabad & 52 & Telangana \\
\hline $\mathbf{7}$ & Lucknow & 52 & Uttar Pradesh \\
\hline $\mathbf{8}$ & Nagpur & 48 & Maharastra \\
\hline $\mathbf{8}$ & Jaipur & 48 & Rajasthan \\
\hline $\mathbf{9}$ & Kolkata & 45 & West Bengal \\
\hline $\mathbf{1 0}$ & Chandigarh & 44 & Chandigarh \\
\hline $\mathbf{1 0}$ & Thane & 44 & Maharastra \\
\hline Total & & $\mathbf{1 2 6 4}$ & \\
\hline
\end{tabular}

Table 8: District Wise Implementation Statistics of e-Granthalaya (Top 10) [22]

In the case of district-wise implementation, New Delhi with 456 implementations obtained top position \& far behind from the others. Mumbai \& Pune with 166 \& 101 implementations, respectively, are in the exact next position. Moreover, the total implementation of all top 10 districts covers more than $24 \%$ of the all-country-wise implementation. (see Table 8)

\section{Findings and Suggestions:}

The study discusses the root causes of the issues associated with the conventional library management framework and provides the advantages, issues \& challenges of using cloud-enabled technology when introducing library automation. Cloud services eliminate 
duplication data creation \& efforts, library resources utilise more because of better accessibility \& visibility, scalable enough for integration with existing systems, less maintenance (cloud-enabled SAAS model), provision of on-cloud security $\&$ authentication and central database \& backup-restore system offered disaster recovery challenge. The architectural vision of NIC National Cloud/GI Cloud, Meghraj displays that is distributed in multiple National \& State Cloud; accepts SWANs, NKN, NOFN integration; \& structured its policies by adopting a set of common Indian government protocols, guidelines and standards. The study also reveals that non-only in India, most international governments are looking to explore cloud computing for managing their e-Governance infrastructure. Meghraj provides four types of cloud model services, viz. IAAS, PAAS, SAAS \& STASS. Among them, e-Granthalaya, a famous cloud-enabled government-supported proprietary software (ILMS), run using a multitenet SaaS model of Meghraj. e-Granthalaya version 4.0 (eG4) is an enterprise edition, which includes subscription provision and the network \& cluster model remains as eG3 but it is built upon the cloudready environment. Among the 46 library clusters, JNV Libraries Network Cluster No. 1 \& JNV Libraries Network Cluster No. 2 are top two clusters with contains $300 \& 287$ libraries, respectively. eGranthalaya gives the provision of Web-Based OPAC, Mobile Based OPAC \& Android Mobile App for implementation \& use of eGranthalaya in any library. To date, 5364 official implementations have been completed, including 5163 in various states in India. These implementations include Maharastra as a top State (with 797 implementations) and New Delhi as a top District (with 456 implementations) in terms of implementations in India.

In this modern era, automation \& digitisation is a common practise in every sector of our society. Huge storage, mobility, backup option, integration, easy transfer, security, durability and such thousands of specialities of cloud-enabled system provoke governments of every country for looking \& explore cloud-enabled management system in every government sector. In India. government-supported cloud service Meghraj must be a first prior option for every government sector. Again, after studying the features \& functionality of e-Granthalaya ILMS (latest version eG4) it should be suggested that it is best for the special libraries and libraries whose collection is not more than 50,000 i.e. its capacity is limited. However, it is easy to fictionalise and by undergoing proper training, the library 
professional can use it more elaborately.

\section{Conclusions:}

Progress in e-Government service delivery technologies is occurring with a significant pace around the Globe. Recent attention has shifted away from the traditional e-Government to a new initiative called G-Cloud. There is a need for standardisation of e-Governance services, which will lead to Simplification of e-Governance service delivery mechanism as well as Synchronisation of activities of various wings of the Government machinery as well as various ministries. In standardising activities for effective implementation of ICT in eGovernance 3 stakeholders i.e. Government, Business \& Citizens must walk together in collaboration. This is the purpose of the creation of GI Cloud/National NIC Cloud Meghraj. The ILMS, e-Granthalaya, are designed by NIC to meet the requirements of different library groups. Promoting ICT \& automation in library management at affordable prices and providing the full flexibility needed by a librarian is the main objective of using e-Granthalaya.

\section{References:}

1. Ministry of Electronics \& Information Technology, Government of India, "National e-Governance Plan".Internet: https://www.meity.gov.in/divisions/national-e-governance-plan, May 18, 2006 [Dec. 12, 2020].

2. D. G. Chandra, M. Kathing, and D. P. Kumar, "Library Automation in Cloud," in Proc. of the 2013 5th International Conference on Computational Intelligence and Communication Networks, Sep. 2013, pp. 474-479. doi: 10.1109/cicn.2013.104.

3. A.K. Tyagi and V. Senthil, "Library Automation in India: Assessment of Library Services Platforms," DESIDOC Journal of Library and Information Technology, vol. 35, no. 6, pp. 408-416, Nov. 2015, doi: 10.14429/djlit.35.6.8895.

4. N. Srivastava, "MeghRaj A Cloud Environment for e-governance in India," International Journal of Computer Sciences and Engineering, vol. 6, no. 11, pp. 759-763, Nov. 2018, doi: 10.26438/ijcse/v6il1 1.759763 .

5. Sandeep. "A Study on the open Source Digital Library Software's: Special Reference to DSpace, E-Granthalaya and Library Management System." International Journal of Engineering Research \& Technology, vol. 3, no. 10, pp. 1-4, NCETEMS - 2015.

6. F. Mohammed and O. Ibrahim. "A Survey on Cloud Government 
Models," presented at the 1st International Conference of Recent Trends in Information and Communication Technologies, UTM, Malaysia, Sept. 2014.

7. R. P. Akula, V. B. Narasimha and M. L. Saikumar. "e-Governance services using Cloud Computing Services" International Journal of Advanced Computer Research, vol. 3, no. 3, issue 11, pp. 139-144, Sept. 2013.

8. D. G. Chandra and R. S. Bhadoria. "Cloud Computing Model for National E-governance Plan (NeGP)," in CICN'12: Proceedings of the 2012 Fourth International Conference on Computational Intelligence and Communication Networks (CICN), Nov. 2012, pp. 520-524, doi: 10.1109/cicn.2012.61.

9. D. Barman and K. Das. "Features of e-Granthalaya: A Case Study among the Special Libraries of Greater Guwahati," presented at the 13th MANLIBNET Annual Convention on Repositioning Libraries for User Empowerment: Policy, Planning and Technology, Delhi University South Campus, Delhi, October 2011.

10. R. K. Matoria, P. K. Upadhyay and M. Moni. "Automation and Networking of Public Libraries in India Using the E-Granthalaya Software from the National Informatics Centre." Programme: Electronic Library and Information Systems, vol. 41, no. 1, pp. 47-58, 2007. doi: $10.1108 / 00330330710724881$

11. S. Majumdar. "Role of Government libraries in the e-Governance in India." Internet: http://aplapindia2005.nic.in/parliament\%20LibraryPresentationmajumdar.pdf, 2015 [17 Dec. 2020].

12. E. Allen, "A Half Century of Library Computing". Internet: https://blogs.loc.gov/loc/2014/01/a-half-century-of-library-computing/, Jan. 15, 2014 [Dec. 13, 2020].

13. S. Bhatnagar, "Cloud computing- Resource management for effective Egovernance," CSI Communication, pp. 29-34, Nov. 2010.

14. "Government of India"s GI Cloud (Meghraj) Strategic Direction Paper", Department of Electronics \& Information Technology, April 2013

15. IBM, "IaaS PaaS SaaS Cloud Service Models". Internet: https:/Www.ibm.com/in-en/cloud/learn/iaas-paas-saas [Dec. 15, 2020].

16. "MeghRaj Cloud Initiative, National cloud by NIC", Ministry of Electronics \& Information Technology, August 2007

17. e-Granthalaya, "e-Granthalaya :A Digital Agenda For Library Automation and Networking". Internet: https://egranthalaya.nic.in/eg4.html, 2015 
[Dec. 15, 2020].

18. R. K. Matoria and R. K. Akunuri, "eG4 User Manual.". Internet: https://egranthalaya.nic.in/Download/eG4_UserManual.pdf, Mar. 25, 2020 [Dec. 18, 2020].

19. R. K. Matoria, "eG3 User Manual." Internet: https://egranthalaya.nic.in/Download/eG3_UserManual.pdf, Jul. 04. 2011 [Dec. 18, 2020].

20. e-Granthalaya, "e-Granthalaya on Cloud: e-Granthalaya 4.0." Internet: https://eg4.nic.in/ [Dec. 16, 2020].

21. e-Granthalaya, "e-Granthalaya: A Digital Agenda for Library Automation and Networking". Internet: https://eg4.nic.in/demo/, 2020 [Dec. 16, 2020].

22. e-Granthalaya, "eGranthalaya Map". Internet: https://egranthalaya.nic.in/EGMap.html, 2020 [Dec. 16, 2020]. 